\title{
Microcephaly caused by the Zika virus: dental care
}

\author{
Microcefalia por Zika vírus: cuidados odontológicos
}

\author{
Juliana da Silva MORO' ${ }^{1}$ iD 0000-0001-9011-9600 \\ Tatiane MAREGA ${ }^{1}$ iD 0000-0002-0647-945X \\ Fernanda Urbini ROMAGNOLO' ${ }^{1}$ (D) 0000-0001-8500-4681
}

\begin{abstract}
Zika virus infection was declared a public health emergency at national and international levels due to the high incidence of the virus infection and its relationship with the birth of children with microcephaly. Patients with microcephaly present significant clinical neuropsychomotor disorders, therefore, dental surgeons should be prepared to treat such patients, observing the possible alterations associated with this condition, as well as the oral diseases. Thus, the purpose of this research study was to inform dental surgeons about the microcephaly associated with the Zika virus, as well as instructing them about the dental care necessary for such condition and its management during the consultations.
\end{abstract}

Indexing terms: Dentistry. Microcephaly. Zika virus.

\section{RESUMO}

A infecção pelo Zika vírus foi declarada como Emergência de Saúde Pública a nível Nacional e Internacional em decorrência da alta incidência de infecção pelo vírus e a sua relação com o nascimento de crianças com microcefalia. Pacientes com microcefalia apresentam alterações neuropsicomotoras de relevância clínica e devido a isso, o cirurgião dentista deve estar preparado para o atendimento e acolhimento desses pacientes, observado as possíveis alterações associadas a essa condição, bem como as alterações bucais presentes. Portanto, o objetivo dessa revisão foi informar o cirurgião-dentista sobre a microcefalia associada ao Zika vírus, assim como orientar sobre os cuidados odontológicos e manejo durante as consultas.

Termos de indexação: Odontologia. Microcefalia. Zika vírus.

\section{INTRODUCTION}

In 2007, due to an infection outbreak caused by the Zika virus in the Pacific Island, reaching the Brazilian territory in early 2015, the virus was considered a public health problem by several authorities, and a worldwide emergency was decreed $[1,2]$. Concurrently with the Zika epidemic, there was an increase in the number of babies born with microcephaly in the Northeast Brazil. After several investigations, the virus was considered a causal factor in the development of microcephaly in fetuses and newborns [3-5].

\footnotetext{
$\operatorname{rrv}$
}

1 Faculdade São Leopoldo Mandic, Instituto de Pesquisas São Leopoldo Mandic, Programa de Pós-Graduação para Pacientes com Necessidades Especiais. Rua José Rocha Junqueira, 13, Swift, 13045-755, Campinas, SP, Brasil. Correspondência para / Correspondence to: JS MORO. E-mail: <juliana.moroo@hotmail.com>.

$\boldsymbol{\nabla} \mathbf{v}$

How to cite this article

Moro JS, Marega T, Romagnolo FR. Microcephaly caused by the Zika virus: dental care. RGO, Rev Gaúch Odontol. 2019;67:e2019001. http:// dx.doi.org/10.1590/1981-86372019000013597 
Microcephaly is considered a disorder that is characterized by the presence of a lower than normal head circumference [6]. In addition, this disfunction may be associated with muscular, neurological, hearing, behavioral and further complications [5,7-9]. As a result, and due to the increasing number of children born with microcephaly caused by the Zika virus $[10,11]$, dental surgeons should be prepared to treat these patients and instruct those responsible for these children about the importance of the oral health. Therefore, this current research study aimed at performing a literature review to inform oral care professionals about the microcephaly caused by the Zika virus, as well as instructing them about the correct approach when treating these patients.

\section{Epidemiology and general aspects of the Zika virus infection}

The Zika virus belongs to the genus Flavivirus in the family Flaviviridae, being, usually, transmitted by the mosquito of the genus Aedes [12]. This virus was isolated, for the first time, in the serum of a Rhesus monkey in the Zika forest in Uganda, in 1947 [13]. Some years later, the same virus was identified in the Aedes egypti mosquito in Malaysia and in other Asian countries [14]. However, due to the existence of sporadic cases of the Zika infection, little attention was given to the epidemic [15].

In 2007, the virus gained the attention of the scientific community due to an infection outbreak, with more evident clinical manifestation in the Federal States of Micronesia, located in the Pacific Ocean [1]. Six years after this outbreak, another one was reported in French Polynesia, reaching, approximately, 28,000 people [16]. In the American continent, Zika was first confirmed in Chile in 2014, and, in early 2015, in the Brazilian territory [2]. In 2015, in Brazil, 18 states reported patients infected by the virus, most of them were concentrated in the Northeast region [17]. Since then, other neighboring countries presented cases of infection spreading to South America, Central America and the Caribbean, totaling 14 new territories [2]. As a result of this and its clinical consequences, the World Health Organization decreed an international public health emergency', directing all the efforts and research studies to this epidemic [18]. Recently, according to a report published by the Pan-American Health Organization, the confirmation is that the Zika virus infection is in 48 territories of the Americas [19].
Considering the Zika virus transmission, additionally to the mosquito, other factors may be associated with it such as pregnancy, sexual contact and blood transfusion [20]. During the pregnancy, the woman, carrying the virus, may transmit it through the amniotic fluid, since the viral RNA was found in it, causing significant damage to the fetus [21]. On the other hand, in breastfeeding, although the virus has been detected in breast milk, data are still very limited regarding the infection caused through this route, requiring additional studies [22]. The sexual transmission was considered a potential route of infection due to the high viral load found in the semen, as well as reports of the disease transmission after the sexual act from infected patients to non-infected ones were published [23]. In relation to blood transfusion, patients who underwent this procedure and received contaminated blood were infected by the Zika virus [24].

The symptoms resulting from the Zika virus infection may be several, presenting, or not, low fever, maculopapular rash, myalgia, arthralgia, headache, conjunctival hyperemia and, less frequently, edema, odynophagia, dry cough and gastrointestinal disorders, especially vomiting. Patients suspected of having Zika infection should show maculopapular pruritic along with two or more of the following symptoms: fever, conjunctival hyperemia without secretion and pruritus, periarticular edema or polyarthralgia $[4,20]$.

The differential diagnosis with other known diseases such as dengue, measles, rubella, chikungunya, among others, should be performed, since some symptoms often resemble each other. Therefore, careful analysis of the symptoms, as well as the collection of biological samples for laboratory tests, should be carried out [25].

\section{Microcephaly and Zika virus}

In 2015, in Brazil, the State Department of Health from Pernambuco notified the Ministry of Health about an increasing number of cases of microcephaly, leading to a data survey on the possible causes of such occurrence. From the information collected, it was suggested a causal relationship of microcephaly to the Zika virus infection [4].

In 2016, a total of 8,165 microcephaly cases were reported in Brazil. And, out of these cases, a total of 1,638 cases were associated with the Zika virus [26]. In the same year, Araújo et al. [3] carried out a case- 
control study investigating the association between the microcephaly and the transmission by the Zika virus during pregnancy. Thus, neonates presenting microcephaly (cases) and those who did not present it (controls), born in eight public hospitals in Pernambuco, were analyzed, totaling 32 cases and 62 controls. The analysis was performed using serum and cerebrospinal fluid samples from the patients tested for IgM to Zika virus. From the data found in this current research study, the authors suggested that the microcephaly was caused by the virus infection, since 24 out of 30 mothers of the babies with microcephaly had Zika infection, as well as 13 of the neonates born with microcephaly were tested positive for the virus by serum or cerebrospinal fluid IgM.

In Colombia, between 2015 and 2016, according to a report from the Colombia's National Institute of Health, 476 cases of microcephaly were reported and, after laboratory tests, it was observed that $48 \%$ of the cases had the Zika virus infection. Also, according to the study, the first quarter of pregnancy and the beginning of the second period are at higher risk for the fetus to develop microcephaly caused by the Zika virus. However, despite of this high percentage of cases in the country, comparing to Brazil, these were three times smaller, being possibly associated with several factors such as the place of residence of the majority of the Colombian population, which is at high altitudes, in which the mosquito is not present, or due to the difficulty in monitoring the microcephalic in newborns, reducing the number of confirmed cases [27].

In 2016, in Vietnam, 23 cases of Zika virus infection were identified. During this period, a case of microcephaly caused by the virus was reported, in which the mother presented symptoms such as fever and rash in the second semester of pregnancy. After the suspicion of infection, laboratory tests were performed confirming the exposure to the virus [28].

In 2015, another case of microcephaly was reported in Brazil. The case was from a 17-year-old pregnant woman, living in the Northeast Brazil, who sought for prenatal care. After the ultrasound was performed, pregnancy of twins was diagnosed and, in both babies, a small circumference of the head was confirmed, suspecting from microcephaly. After birth, the diagnosis of microcephaly was confirmed and the serological tests excluded rubella, toxoplasmosis, syphilis among other diseases. Subsequently, serological tests were performed for the Zika virus, confirming the virus in the mother of the newborns [29].
A systematic review conducted recently, aimed at finding scientific evidences associating the Zika virus infection and the microcephaly. Included in this review, there were studies from every language that was within a pre-established framework of the Zika virus causality. The reference sources were databases and electronic sites from the year 2016. After a careful analysis of the studies, 87 items were included. Based on the results, the authors concluded that the Zika virus infection, during pregnancy, is associated with the microcephaly in fetuses and newborns [30].

\section{Microcephaly: diagnosis and clinical aspects}

Microcephaly is a congenital condition characterized by a lower than normal cephalic perimeter and may be present at birth (congenital microcephaly) or after birth (acquired microcephaly) [6]. According to the WHO, to be considered microcephaly, the cranial measurement should be less than two standard-deviation below average, according to the age and the gestational gender. The cephalic perimeter is measured with a non-stretchable measuring tape, which is placed around the circumference of the newborn's head (at the height of the supraorbital arches and the greater prominence of the occipital bone), preferably within 24 hours after birth [31].

It is important to note that the measure of the head circumference may vary according to the gestational age and the ethnical characteristics, therefore, they should be considered during the anamnesis and physical examination. According to the WHO and the INTERGROWTH-21st fetal growth patterns, in the first 24 - 48 hours of the newborn's life, the average referential cephalic measurement corresponds to $34.5 \mathrm{~cm}$ for boys and $33.9 \mathrm{~cm}$ for girls [32]. With regards to the measurements related to microcephaly, the Brazilian Ministry of Health, in 2016, adopted new parameters, in which the cephalic measurement should be equal to or lower than 31.9 centimeters for boys, and equal to or lower than 31.5 centimeters for girls [31].

In addition to detailed anamnesis and measurement of the child's head circumference, additional tests should be performed to properly make the diagnosis, comprising neurological examinations, observing the newborn's posture, the spontaneous movements, the crying reflex and the primitive reflexes (sucking, holding, gait, cutaneousplantar and Moro) [33]. Furthermore, imaging exams are 
also essential as they allow the visualization of dysfunctions in the central nervous system, comprising obstetric ultrasonography, transfontanelar ultrasonography and cranial CT scan [34].

Microcephaly may be associated with other dysfunctions such as muscle stiffness and limb contractures, convulsions, irritability, swallowing problems, hearing and eye abnormalities, brain anomalies, brainstem dysfunction and cerebral cortex calcification [5,7-9]. In a cohort study conducted in two pediatric hospitals in Berlin, the objective was to evaluate the diagnosis of microcephaly cases. A total of 680 children with microcephaly from both genders were evaluated. Information regarding medical history, clinical, laboratory, genetic and radiographic data were collected. At the end of the study, the authors observed intellectual impairment disability (65\%), epilepsy (43\%), ophthalmological dysfunction (30\%) and brain abnormalities in the patients [10].

\section{The Dental Surgeon's Work}

In most cases, the microcephaly is associated with other congenital disorders which are relevant to the dental practice such as swallowing problems, mental retardation, epilepsy etc [9]. As a result, the dental surgeon should be prepared to treat these patients and guide-orient the family regarding the patient's oral care. In the first appointment, a detailed anamnesis should be carried out, considering the medical history, the physical and mental limitations and the patient's current health [35]. Newborns with neurological disorders, such as the microcephaly, may present difficulties in oral motor skills, therefore, the professional should instruct the parents about breastfeeding, breathing and swallowing [36].

Breastfeeding is essential for the newborn due to its nutritional and emotional importance. In addition, breastfeeding establishes appropriate muscle tone, positively influencing the development of the stomatognathic system [37]. However, children without suctioning, swallowing and breathing coordination, such as patients with microcephaly, are at risk for aspiration and choking. Thus, alternatives should be presented to parents such as the use of glasses/cups, finger probes, among others [38].

Instruction about oral hygiene, healthy diets and habits should be provided by dental surgeons since the beginning of pregnancy, as it has a positive influence on the oral health of the child [39]. Children with intellectual impairment present higher rate of caries and periodontal disease, as well as inadequate oral hygiene [40]. Moreover, the difficulty to have access to specialized services and the lack of the patient's cooperation also result in poor oral health in patients with special needs [41].

Children with microcephaly often show convulsive seizures [10], therefore, it is essential for the success of the treatment to investigate the factors that trigger the seizures, as well as the medications of continuous use [42]. Some drugs, such as the phenytoin, can cause gingival hyperplasia, making it difficult chewing and oral hygiene [43]. Then, it is necessary to show to the family the importance of taking the patient to the appointments for prophylaxis and biofilm control. Besides the side effects, attention should be given to drug interaction in patients undergoing treatment with anticonvulsants [44]. For example, benzodiazepines, CNS depressant drugs, should be prescribed with caution, as potential interaction may occur, leading to a greater CNS depressant effect [45].

Another important aspect is managing the patient's behavior during treatment. These patients demand shorter and quieter consultations for both simple and complex procedures. Treatment should be performed, whenever possible, in stages. The communication with the child must be clear and compatible with their ability to understand [46].

In cases where the patients are not very collaborative, stabilization measures can be performed, provided they have the consent from those responsible for the patient. Another option are the drugs to promote moderate sedation, such as benzodiazepines, however, it is very important to observe the recommended doses and possible drug interactions. When the treatment can not be performed in an outpatient clinic, the patient should be referred to a hospital and the treatment performed under general anesthesia [47].

\section{FINAL CONSIDERATIONS}

Faced with the increasing number of infection caused by the Zika virus and the new cases of children born with microcephaly, dental surgeons should be prepared to treat these patients. Therefore, knowing the dysfunctions associated with microcephaly and the main oral problems 
of the patient help in directing the treatment care, aiming at achieving a better technical management and clinical behavior during treatment.

Collaborators

IS MORO, T MAREGA and FR ROMAGNOLO: selection of articles, review of manuscript writing and approved the final version.

\section{REFERENCES}

1. Samarasekera U, Triunfol M. Concern over Zika virus grips the world. Lancet. 2016; 387(10018):521-25. http://dx.doi. org/10.1016/S0140-6736(16)00257-9

2. Pan American Health Organization. Neurological syndrome, congenital malformations, and Zika virus infection. Implication for public health in the Americas. Washington, D.C: Pan American Health Organization; 2015.

3. de Araújo TVB, Rodrigues LC, de Alencar Ximenes RA, de Barros Miranda-Filho D, Montarroyos UR, de Melo APL, et al. Association between Zika virus infection and microcephaly in Brazil, January to May, 2016: preliminary report of a casecontrol study. Lancet Infect Dis. 2016;16(12):1356-1363. http://dx.doi.org/10.1016/S1473-3099(16)30318-8

4. Brasil. Ministério da Saúde. Secretaria de Atenção à Saúde. Protocolo de atenção à saúde e resposta à ocorrência de microcefalia relacionada à infecção pelo vírus zika [online]. Brasília: Ministério da Saúde; 2016 [citado 2018 Jul 10]. Disponível em: <http://bvsms.saude.gov.br/bvs/publicacoes/ protocolo_resposta_microcefalia_relacionada_infeccao_ virus_zika.pdf>.

5. Mlakar J, Korva M, Tul N, Popović M, Poljšak-Prijatelj M, Mraz J, et al. Zika Virus Associated with Microcephaly. N Engl J Med. 2016;374(10):951-8. http://dx.doi.org/10.1056/ NEJMoa1600651

6. Abuelo D. Microcephaly syndromes. Semin Pediatr Neurol. 2007; 14(3):118-27.

7. Freitas BP, Dias JRO, Prazeres J. Ocular findings in infants with microcephaly associated with presumed zika virus congenital infection in Salvador, Brazil. JAMA Ophthalmol. 2016;134(5):529-535.

jamaophthalmol.2016.0267

8. Ventura CV, Maia M, Dias N, Ventura LO, Belfort Junior R. Zika: neurological and ocular finding in infants without. Microcephaly. 2016;387(10037):250. https://doi.org/10.10 16/S0140-6736(16)30776-0

9. Moore CA, Staples JE, Dobyns WB, Pessoa A, Ventura CV, Fonseca $E B$, et al. Characterizing the pattern of anomalies in congenital Zika syndrome for pediatric clinicians. JAMA Pediatr. 2017;171(3):288-295. https://doi.org/10.1001/jama pediatrics.2016.3982
10. von der Hagen M, Pivarcsi $M$, Liebe J, von Bernuth $H$, Didonato N, Hennermann JB, et al. Diagnostic approach to microcephaly in childhood: a two-center study and review of the literature. Dev Med Child Neurol. 2014;56(8):732-41. https://doi.org/10.1111/dmcn.12425

11. Brasil. Ministério da Saúde. Secretaria de Vigilância em Saúde. Portaria $n^{\circ}$ 1.813, de 11 de Novembro de 2015. Declara Emergência em Saúde Pública de importância Nacional (ESPIN) por alteração do padrão de ocorrência de microcefalias no Brasil. Brasil. Ministério da Saúde; 2015 [citado 2018 Jul 10]. Disponível em: <http://bvsms.saude.gov.br/bvs/saudelegis/gm/ 2015/prt1813_11_11_2015.html>.

12. Lindenbach BD, Thiel HJ, Rice CM. Flaviviridae: the viruses and their replication. In: Knipe, DM, Howley PM, Griffin DE, Lamb RA, Martin MA, Roizman B, et al. Pandemic in progress and an epidemiological challenge. Rev Colomb Anestesiol. 2016;4 4(2):86-8.

13. Oliveira CS, Vasconcelos PFC. Microcephaly and Zika vírus. J Pediatr (Rio J). 2016;92(2):103-105. http://dx.doi.org/10. 1016/j.jped.2016.02.003

14. Hayes EB. Zika virus outside Africa. Emerg Infect Dis 2009;15:1347-50. http://dx.doi.org/10.3201/eid1509.090442

15. Besnard M, Lastere S, Teissier A, Cao-Lormeau V, Musso D. Evidence of perinatal transmission of Zika virus, French Polynesia, December 2013 and February 2014. Euro Surveill. 2014;19(13):20751

16. Brasil. Ministério da Saúde do Brasil. Relatório do Centro de operações de emergência em saúde pública nas microcefalias. Brasil. Ministério da Saúde do Brasil; 2015 [citado 2018 Jul 10]. Disponível em: <http://portalsaude.saude.gov.br/index. php/cidadao/principal/agencia-saude/20925-ministerio-divulgaboletim-epidemiologico. 2015a>.

17. World Health Organization. Statement on the first meeting of the International Health Regulations 2005 (IHR 2005) Emergency Committee on Zika virus and observed increase in neurological disorders and neonatal malformations. Geneva: World Health Organization; 2016.

18. Pan American Health Organization. Zika: actualización epidemiológica. Washington, D.C: Pan American Health Organization; 2017.

19. Song BH, Yun SI, Woolley M, Lee YM. Zika virus: history, epidemiology, transmission, and clinical presentation. J Neuroimmunol. 2017;308:50-64. http://dx.doi.org/10.1016/j. jneuroim.2017.03.001

20. Calvet G, Aguiar RS, Melo ASO, Sampaio SA, Filippis I, Fabri $A$, et al. Detection and sequencing of Zika virus from amniotic fluid of fetuses with microcephaly in Brazil: a case study. Lancet Infect Dis. 2016;16(6):653-60. https://doi.org/10.10 16/S1473-3099(16)00095-5

21. Cavalcanti MG, Cabral-Castro MJ, Gonçalves JLS, Santana LS, Pimenta ES, Peralta JM. Zika virus shedding in human milk during lactation: an unlikely source of infection? Int J Infect Dis. 2017;57:70-72. https://doi.org/10.1016/j.ijid.2017.01.042

22. Haddow AD, Nalca A, Rossi FD, Miller LJ, Wiley MR, Perez-Sautu U, et al. High Infection Rates for Adult Macaques after Intravaginal or Intrarectal Inoculation with Zika Virus. Emerg 
Infect Dis. 2017;23(8):1274-1281. https://doi.org/10.3201/ eid2308.170036

23. Backer CL. Blood and the Zika vírus. J Thorac Cardiovasc Surg. 2017;154(1):305. https://doi.org/10.1016/j.jtcvs.2017. 03.028

24. Santa Catarina (Estado). Secretaria de Estado da Saúde. Diretoria de Vigilância Epidemiológica. Nota técnica n. 07/ DIVE/SUV/SES/2015 (Atualizada em 29/1/2016): Assunto: procedimentos a serem adotados em Santa Catarina frente a caso suspeito de Febre do Zika Vírus (ZIKAV). 2016 [citado 2017 Ago 2]. Disponível em: <http://www.dive.sc.gov.br/ conteudos/zoonoses/notas-tecnicas/Nota_ Tenica_Geral_Zl KAV_REVISADA.pdf>

25. Brasil P, Pereira JP Jr, Moreira ME, Ribeiro Nogueira RM, Damasceno $L$, Wakimoto $M$, et al. Zika virus infection in pregnant women in Rio de Janeiro. N Engl J Med. 2016;375(24):2321-34.

26. Cuevas EL, Tong VT, Rozo N, Valencia D, Pacheco O, Gilboa SM. Preliminary report of microcephaly potentially associated with Zika virus infection during pregnancy - Colombia, January-November 2016. MMWR. 2016;65.

27. Moi ML, Nguyen TTT, Nguyen CT, Vu TBH, Tun MMN, Pham $T D$, et al. Zika virus infection and microcephaly in Vietnam. Lancet Infect Dis. 2017 Aug;17(8):805-806. https://doi. org/10.1016/S1473-3099(17)30412-7

28. Santos VS, Oliveira SJG, Gurgel RQ, Lima DRR, Dos Santos CA, Martins-Filho PRS. Case Report: microcephaly in twins due to the Zika Virus. Am J Trop Med Hyg. 2017;97(1):151154. https://doi.org/10.4269/ajtmh.16-1021

29. Krauer F, Riesen M, Reveiz L, Oladapo OT, Martínez-Vega R, Porgo TV. Zika virus infection as a cause of congenital brain abnormalities and guillain-barré syndrome: systematic review. PLoS Med. 2017;14(1):e1002203. https://doi.org/10.1371/ journal.pmed.1002203

30. Brasil. Ministério da Saúde. Secretaria de Vigilância em Saúde. Departamento de Vigilância das Doenças Transmissíveis. Protocolo de vigilância e resposta à ocorrência de microcefalia e/ou alterações do sistema nervoso central (SNC). Versão 2. Brasília: Ministério da Saúde; 2016 [citado 2017 Ago 2]. Disponível em: <http://combateaedes.saude.gov.br/images/ sala-de-situacao/Microcefalia-Protocolo-de-vigilancia-eresposta-10mar2016-18h.pdf>.

31. World Health Organization. Child growth standards. Head circumference-for-age [citado 2017 Ago 2]. Disponível em: $<$ http://www.who.int/childgrowth/standards/hc_for_age/ en/s.

32. Gherpelli JL. Propedêutica neurológica do recém-nascido e sua evolução. Rev Med (São Paulo). 2003;82(1-4):22-33. https://doi.org/10.11606/issn.1679-9836.v82i1-4p22-33

33. Staples JE, Dziuban EJ, Fischer M, Cragan JD, Rasmussen SA, Cannon MJ, et al. Interim guidelines for the evaluation and testing of infants with possible congenital Zika virus infection - United States, 2016. MMWR Morb Mortal Wkly Rep. 2016; 65:63-7.
34. Brasil. Ministério da Saúde. Secretaria de Atenção à Saúde. Diretrizes de estimulação precoce: crianças de zero a 3 anos com atraso no desenvolvimento neuropsicomotor decorrente de microcefalia. Brasília: Ministério da Saúde; 2016 citado 2017 Ago 2]. Disponível em: < http://portalarquivos2. saude.gov.br/images/pdf/2016/janeiro/13/Diretrizes-deEstimulacao-Precoce.pdf $>$.

35. Leite CN, Varellis MLZ. Microcefalia e a odontologia brasileira. J Health NPEPS. 2016;1(2):297-304.

36. Bervian, J, Fontana M, Caus B. Relationship among breastfeeding, oral motor development and oral habits literature review. RFO. 2008;13(2):76-81.

37. Moreira CMD, Cavalcante-Silva RPGV, Fujinaga Cl, Marson F. Comparison of the finger-feeding versus cup feeding methods in the transition from gastric to oral feeding in preterm infants. J Pediatr (Rio J). 2017;93(6):585-591. https:// doi.org/10.1016/j.jped.2016.12.008

38. Rigo L, Dalazen, J, Garbin RR. Impacto da orientação odontológica para mães durante a gestação em relação à saúde bucal dos filhos. Einstein (São Paulo). 2016;14:219-2 25.

39. Garcés CP, Barrera ML, Ortiz ME, Rosas CF. Estado de salud oral de niños y adolescentes con discapacidad intelectual en una población chilena. J Oral Res. 2012;2(2):59-63.

40. de Jongh A, van Houtem C, van der Schoof M, Resida G, Broers D. Oral health status, treatment needs, and obstacles to dental care among noninstitutionalized children with severe mental disabilities in The Netherlands. Spec Care Dentist. 2008;28(3):111-5. https://doi.org/10.1111/j.1754-450 5.2008.00022.x

41. Baumgartem A, Cancino CMH. Epilepsia e Odontologia: uma revisão da literatura. Rev Bras Odontol. 2016;73(3):231-6.

42. Chen B, Choi H, Hirsch LJ, Moeller J, Javed A, Kato K, et al. Cosmetic side effects of antiepileptic drugs in adults with epilepsy. Epilepsy Behav. 2015;42:129-37. https://doi.org/10. 1016/j.yebeh.2014.10.021

43. Robbins M. Dental management of special needs patients who have epilepsy. Dent Clin North Am. 2009 Apr;53(2):295309. https://doi.org/10.1016/j.cden.2008.12.014

44. Sehn R, Camargo AL, Heineck I, Ferreira MBC. Interações medicamentosas potenciais com benzodiazepínicos em prescrições médicas de pacientes hospitalizados. Rev Ciênc Farm Básica Apl. 2014;35(4):589-96.

45. Lawton L. Providing dental care for special patients. Tips for the general dentist. J Am Dent Assoc. 2002;133(12):1666-70. https://doi.org/10.14219/jada.archive.2002.0118

46. Levy $H$, Rotemberg L. Tools and equipment for managing special care patients anywhere. Dent Clin North Am. 2016;60(3):567-91. doi: 10.1016/j.cden.2016.03.001

Received on: 23/3/2018 Final version resubmitted on: 8/5/2018 Approved on: 8/6/2018 